\title{
Excessive Dietary Selenium to Primiparous Sows and their Offspring
}

\section{Influence on reproduction and growth}

\author{
By Hanne Damgaard Poulsen, Viggo Danielsen, Thomas Krogh Nielsen and \\ Conny Wolstrup
}

National Institute of Animal Science, Department for Research in Pigs and Horses, Foulum, and National Veterinary Laboratory, Copenhagen, Denmark.

\begin{abstract}
Poulsen, H. D., V. Danielsen, T. K. Nielsen and C. Wolstrup: Excessive dietary selenium to primiparous sows and their offspring. I. Influence on reproduction and growth. Acta vet. scand. 1989, 30, 371-378. - The effect of high dietary selenium (Se) on the reproductive performance, growth and health in pigs was examined. Addition of 0 to $16 \mathrm{mg}$ Se per $\mathrm{kg}$ feed to sows and their piglets up to nine weeks of age did not cause any manifest toxic effect. None of the sows died due to the Se treatment. The piglets were all fullborn and showed no macroscopic abnormalities. The treatment did not influence neither the number of liveborn and stillborn piglets in the litter, nor the survival of the piglets until 9 weeks of age. The weight of the whole litter at birth was unaffected by the Se supplementation, while there was a significant difference in body weight of the piglets at 9 weeks of age. The weaned pigs receiving 8 or $16 \mathrm{mg} \mathrm{Se}$ per $\mathrm{kg}$ feed had a reduced feed intake. As the feed utilization was unaffected by treatment, these pigs had a significantly lower weight at 9 weeks of age.
\end{abstract}

Selenium toxicity; selenosis; piglets; postnatal development.

\section{Introduction}

Selenium (Se) is an essential micronutrient required for prevention of several disease stages of cellular degeneration and cell membrane damage. Since Rotruck et al. in 1973 discovered that Se is an integrated part of the enzyme glutathione peroxidase (GSHPx, E.C. 1.11.1.9) much effort has been made to estimate the levels of Se necessary in diets for pigs to secure optimal physiologic function. In that context most of the experiments carried out are concerning levels of Se in the physiologic range (Chavez 1985, Nielsen et al. 1979, Meyer et al. 1981, all using selenite in their studies). Only a few reports deal with a surplus of Se to pigs. Some of these reports are based on case stories where Se surplus was in charge of having produced the harming effects ( $\mathrm{Ca}$ steel et al. 1985, Harrison et al. 1983, Wilson et al. 1983). These authors did not specify the Se source used in the feed preparations, but the pigs seriously affected developed paralytic disease. Post mortem examinations revealed lesions of the spinal cord. Experiments carried out using sodium selenite revealed that the conception rate, littersize and weight of the piglets were negatively influenced by feeding high dietary Se levels to sows (Wahlstrom \& Olson 1959a). The performance of weanling piglets was affected by high dietary Se resulting in reduced feed intake and rate of gain (Wahlstrom \& Olsson 1959b, Goehring et al. 1984, Mahan \& Moxon 1984).

When comparing investigations on the feed- 
ing of Se, it is important to be aware of the chemical form in which it was given. The aim of the present experiment was to investigate the effect of adding high levels of Se as sodium selenite to the diet for reproducing sows and their piglets. This paper is the first in a series based on results from this experiment.

\section{Materials and methods}

28 female pigs (crossbred Landrace and Yorkshire) were set on trial when they showed their first oestrus and they were mated at their second oestrus. They were fed a diet based on barley and soyaprotein. To this diet $0,2,4,8$ or $16 \mathrm{mg}$ Se per $\mathrm{kg}$ as sodium selenite were added. Two times 4 litter mates and 4 times 5 litter mates were randomly allocated to the treatment groups shown in Table 1.

The composition of the basal diets for the sows during pregnancy and lactation is presented in Table 2. The sows were fed according to a scale. Daily amounts of feed before mating: $2.5 \mathrm{~kg}$; during pregnancy: 2.2 $\mathrm{kg}$ until day $83,3.5 \mathrm{~kg}$ from day 84 to day 111 and $2.6 \mathrm{~kg}$ from day 112 to 2 days post partum; during lactation: $2.0 \mathrm{~kg}$ plus $0.2 \mathrm{~kg}$, $0.3 \mathrm{~kg}$ and $0.4 \mathrm{~kg}$ per piglet in week 1,2 and 3 , respectively; from weaning to mating: 3.5 kg.

The piglets were weaned at 21 days of age. During the suckling period they had no access to creep feed. From 3 to 9 weeks of age they were fed a basal diet ad libitum (Table 2) supplied with the same level of $\mathrm{Se}$ as their mothers' diet.

The body weight of the sows and piglets and the amount of feed ingested were recorded weekly. The number of liveborn and stillborn piglets was recorded.

After injection of oxytocin, samples of colostrum and milk were obtained just after farrowing and 2 weeks post partum, respec- tively. These samples were analysed for the content of fat and protein, and after removal of fat, Se concentrations were determined.

From litters in which the number of liveborn at farrowing was 6 or more, 3 piglets (small, big and medium size) were killed between 36 to $48 \mathrm{~h}$ post partum by injection of pentobarbital intravenously. Tissues for chemical and pathological examination were sampled.

Two sows from each treatment group were slaughtered when new pregnancy was detected. Post mortem the uterus, ovaries and tissue were removed for inspection.

During the experimental period, the sows and piglets were clinically examined.

Contents of protein, fat and fibre were analysed in order to calculate the net energy value (FUp) of the diets (Just 1982). Se in the diets was determined and the Se levels were in accordance with the planned concentrations.

Statistical calculations were performed by use of the GLM procedure in $S A S$ (1982). In analysis of variance the variables tested were corrected for effect of replicate. Furthermore, the least square means estimate of treatments were compared according to the O-hypothesis in the LSMEANS procedure in SAS. The results are delineated in the tables as mean values and standard errors of means.

\section{Results}

The total daily amount of Se given to the sows was higher during lactation than during pregnancy due to the feeding regime. In Table 1 the mean daily Se intake is presented. Sows fed the highest Se level in their diet consumed about 40 and $60 \mathrm{mg}$ Se daily during pregnancy and lactation, respectively. The feed intake of the sows was uninfluenced by the Se concentration in the diet, and the mean weights of the sows did not 
Table 1. Experimental design, daily Se intake and changes in body weight of sows during pregnancy and lactation.

\begin{tabular}{lrrrrrr}
\hline Treatment & 1 & 2 & 3 & 4 & 5 & se m \\
\hline Se suppl. mg per kg feed & 0 & 2 & 4 & 8 & 16 & \\
Number of sows & 6 & 6 & 6 & 6 & 4 & \\
Feed intake, $k g$. & & & & & & \\
$\quad$ during pregnancy & 297 & 301 & 298 & 298 & 305 & \\
$\quad$ during lactation & 77 & 74 & 85 & 82 & 78 & \\
$\quad \begin{array}{l}\text { m Se per day } \\
\quad \text { during pregnancy }\end{array}$ & 0.33 & 5.5 & 10.6 & 20.7 & 42.4 & \\
$\quad$ during lactation & 0.48 & 7.7 & 16.5 & 31.4 & 59.7 & \\
$\quad$ Changes in body welght, $k g$ & & & & & & \\
$\quad$ gain during pregnancy & 73 & 66 & 76 & 75 & 57 & 6 \\
$\quad$ loss during lactation & 9 & 10 & 16 & 10 & 11 & 2 \\
\hline
\end{tabular}

show any significant difference due to treatment as shown in Table 1, although there was a tendency to a reduction in weight gain during pregnancy for the sows on treatment 5.

Some results concerning oestrus, mating and culling of the sows are shown in Table 3.
There was no treatment effect on the conception rate of sows. None of the sows died of Se toxicity, but 2 sows were culled for other reasons. The piglets from 1 sow (treatment 4) were very weak at birth and died within 2 days post partum. This sow was omitted from calculations from the day

Table 2. The basal diet for the sows and the piglets ${ }^{1)}$ : Composition (\%) and analysed contents.

\begin{tabular}{lccc}
\hline & \multicolumn{2}{c}{ Sows } & \\
\cline { 2 - 3 } & pregnancy & lactation & $\begin{array}{c}\text { Piglets } \\
\text { postweaning }\end{array}$ \\
\hline Barley & 79.7 & 76.7 & 33.6 \\
Wheat & - & - & 33.6 \\
Wheat bran & 5.0 & 5.0 & - \\
Soybean meal & 12.0 & 15.0 & 9.0 \\
Fishmeal & - & - & 9.0 \\
Dried skimmilk & - & - & 9.0 \\
Fat & - & - & 3.0 \\
Min. and vit.-suppl. & 3.3 & 3.3 & 2.6 \\
Lysine suppl. & - & - & 0.2 \\
\hline
\end{tabular}

Per kg feed:

$\begin{array}{llll}\text { FUp }^{2)} & 0.96 & 0.97 & 1.13 \\ \mathrm{mg} \mathrm{Se} & 0.13 & 0.13 & 0.34 \\ \text { mg vitamin E } & 24 & 24 & 36\end{array}$

1) According to Danish recommendations.

2) Feed units for pigs (FEs) (Just 1982). 
Table 3. Results concerning mating, conception rate and culling of the sows.

\begin{tabular}{lccccc}
\hline Treatment & 1 & 2 & 3 & 4 & 5 \\
\hline Age at 1st oestrus, days & 195 & 190 & 190 & 186 & 198 \\
$\begin{array}{l}\text { Days } \\
\quad \text { until 1st mating }\end{array}$ & 25 & 26 & 39 & 30 & 31 \\
$\quad$ until 1st pregnancy & 25 & 37 & 45 & 30 & 31 \\
$\quad \begin{array}{l}\text { Number of sows not con- } \\
\quad \text { ceiving at 1st mating }\end{array}$ & 0 & 1 & 1 & 0 & 0 \\
$\quad \begin{array}{l}\text { Days from weaning } \\
\quad \text { to mating }\end{array}$ & 5.6 & 6.0 & 8.3 & $12.0^{1)}$ & 6.0 \\
$\quad$ to 2nd pregnancy & 9.3 & 6.0 & 23.8 & 12.0 & 6.0 \\
$\quad$ Number of sows not con- & & & & & \\
$\quad$ ceiving at 1st mating & 1 & 0 & 2 & 0 & 0 \\
$\quad$ Number of sows culled & 0 & $1^{2)}$ & 0 & 0 & $1^{3)}$ \\
\hline
\end{tabular}

1) One sow gave birth to piglets that died within 2 days post partum. This sow showed new oestrus 28 days later.

2) Culled because of leg problems not related to treatment.

3) This sow died 18 days after weanıng. By post mortem examinations, 4 macerated foetuses were found in the uterus, which was ruptured.

when all her piglets were dead. All other pigs were healthy in every respect. The only clinical observation was a circular dark band in the hoofs of some sows on high Se supplementation, but the locomotion of the sows and the piglets was unaffected.

In colostrum and milk only the content of Se was significantly influenced by treatment (Table 4).

The number of piglets born did not show any significant difference due to the Se-treatment nor did the mortality corrected for littersize after killing up to 9 weeks of age (Table 5). Corrected for littersize, the mean

Table 4. The composition of colostrum and milk

\begin{tabular}{lcccccr}
\hline Treatment & 1 & 2 & 3 & 4 & 5 & s e m \\
\hline Colostrum: & & & & & & \\
$\quad$ Se, mg per kgl) & $0.13^{\mathrm{a}}$ & $0.14^{\mathrm{a}}$ & $0.18^{\mathrm{a}}$ & $0.43^{\mathrm{b}}$ & $0.88^{\mathrm{c}}$ & 0.08 \\
fat, g per kg & 51 & 74 & 79 & 70 & 59 & 14 \\
protein, g per kg & 111 & 105 & 110 & 114 & 120 & 12 \\
Milk. & & & & & & \\
Se, mg per kg) & $0.03^{\mathrm{a}}$ & $0.06^{\mathrm{a}}$ & $0.11^{\mathrm{a}}$ & $0.10^{\mathrm{a}}$ & $0.29 \mathrm{~b}$ & 0.03 \\
fat, g per kg & 74 & 79 & 83 & 85 & 71 & 6 \\
protein, g per kg & 49 & 51 & 50 & 52 & 53 & 1 \\
\hline
\end{tabular}

1) Mean values differ significantly ( $p \leq 0.0001$ ).

2) Mean values differ significantly ( $\leq 0.01$ ).

Mean values that do not share a common superscript are significantly different $(p \leq 0.05)$. 
Table 5. Number and body weight of the piglets from birth unt1l 9 weeks of age.

\begin{tabular}{|c|c|c|c|c|c|c|}
\hline Treatment & 1 & 2 & 3 & 4 & 5 & sem \\
\hline \multicolumn{7}{|l|}{ Piglets per litter } \\
\hline liveborn & 7.5 & 7.2 & 9.3 & 7.8 & 9.0 & 1.1 \\
\hline stillborn & 1.2 & 0.5 & 0.5 & 1.5 & 0.5 & 0.4 \\
\hline total number & 8.7 & 7.7 & 9.8 & 9.3 & 9.5 & 0.9 \\
\hline \multicolumn{7}{|l|}{ Welght of live born, $\mathrm{kg}$} \\
\hline per litter & 11.2 & 11.1 & 14.1 & 10.5 & 12.2 & 1.4 \\
\hline per piglet & 1.53 & 1.59 & 1.53 & 1.37 & 1.35 & 0.10 \\
\hline Piglets killed & 15 & 15 & 18 & 9 & 12 & \\
\hline \multicolumn{7}{|l|}{ Littersize } \\
\hline after kulling & 5.0 & 4.7 & 6.3 & 6.6 & 6.0 & 0.9 \\
\hline at weaning & 4.8 & 4.5 & 5.5 & 5.8 & 5.8 & 0.8 \\
\hline at 9 weeks of age & 4.3 & 4.2 & 5.3 & 5.4 & 5.0 & 0.7 \\
\hline \multicolumn{7}{|l|}{ Mortality per litter } \\
\hline number of piglets & 0.7 & 0.5 & 1.0 & 0.6 & 1.0 & 0.4 \\
\hline \multicolumn{7}{|c|}{ Body weight per piglet, $\mathrm{kg}$} \\
\hline after killıng & 1.56 & 1.54 & 1.55 & 1.44 & 1.37 & 0.10 \\
\hline at weanıng & 6.4 & 6.2 & 6.5 & 5.8 & 5.5 & 0.3 \\
\hline at 9 weeks of age ${ }^{1)}$ & $22.6^{\mathrm{a}}$ & $21.8^{\mathrm{ac}}$ & $21.9^{a}$ & $20.3^{b c}$ & $19.5^{\mathrm{b}}$ & 1.1 \\
\hline
\end{tabular}

1) Mean values differ significantly ( $p \leq 0.05$ ).

Mean values that do not share a common superscript are significantly different $(p \leq 0.05)$.

body weight of the piglets and the weight of the litter was not significantly different, although the piglets born from sows on treatment 4 and 5 tended to have a lower body weight at birth. The Se treatment tended to have a negative influence on the body weight at weaning $(\mathrm{p}=0.08)$.
During the final week on trial the daily Se intake was $18.1 \mathrm{mg}$ for the piglets on treatment 5 (Table 6).

The mean body weight at 9 weeks of age and the mean daily feed intake from weaning until 9 weeks of age differed significantly between treatments (Tables 5 and 6). Ana-

Table 6. Daily selenium consumption and feed intake per piglet from 3 to 9 weeks of age.

\begin{tabular}{lcccccr}
\hline Treatment & 1 & 2 & 3 & 4 & 5 & s e m \\
\hline $\begin{array}{l}\text { Daily Se intake, } m g \text {. } \\
\text { 3 to 9 weeks of age }\end{array}$ & 0.20 & 1.26 & 2.50 & 4.21 & 8.35 & 0.28 \\
$\quad$ during the final week & 0.39 & 2.37 & 4.40 & 7.44 & 18.1 & 1.03 \\
From 3 to 9 weeks of age. & & & & & & \\
daily feed intake, $\mathrm{kg}^{1)}$ & $0.58^{\mathrm{a}}$ & $0.54^{\mathrm{ac}}$ & $0.58^{\mathrm{a}}$ & $0.51^{\mathrm{bc}}$ & $0.51^{\mathrm{b}}$ & 0.02 \\
daily gain, g & 387 & 372 & 366 & 345 & 333 & 25 \\
kg feed per kg gain & 1.50 & 1.46 & 1.57 & 1.49 & 1.58 & 0.06 \\
\hline
\end{tabular}

1) Mean values differ significantly ( $\mathrm{p} \leq 0.01)$.

Mean values that do not share a common superscript are significantly different ( $p \leq 0.05$ ). 
lysis of covariance revealed that the interaction between treatment and the body weight at weaning significantly affected body weight at 9 weeks of age and daily feed intake from weaning until 9 weeks of age ( $p \leq$ 0.05 ). The feed utilization was uninfluenced by the Se-supplementation.

\section{Discussion}

The reproduction results indicate that supplementing sodium selenite as much as 16 $\mathrm{mg}$ Se per $\mathrm{kg}$ did not lead to reproduction disturbances when primiparous sows were fed a barley and soybean meal diet. In contrast, Wahlstrom \& Olson (1959a) reported a depression in conception rate and number of liveborn piglets when young sows were fed a corn and soybean meal diet supplemented with sodium selenite at a level of 10 $\mathrm{mg}$ Se per kg. Their experiment showed a decreased survival rate and body weight of the piglets at weaning ( 8 weeks of age). They pointed out that during the suckling period the piglets consumed some feed from the selenized rations fed to the sows, but the amount of ingested feed was not recorded.

The survival rate of the piglets in the present trial was unaffected by the Se supplement, whereas a Se supplement between 4 and 16 $\mathrm{mg}$ Se per $\mathrm{kg}$ reduced the feed intake and growth rate of the piglets during their first 9 weeks of life. The growth rate was more affected after weaning than during the suckling period, in which the Se challenge was smaller as the Se content in the milk was low compared to the content in the feed. Goehring et al. (1984) and Mahan \& Moxon (1984) in their experiments also found a decline in feed intake and weight gain when the dietary Se levels exceeded $5 \mathrm{mg}$ per $\mathrm{kg}$. The average daily feed intake was reduced by approx. $50 \%$ and the feed utilization was poor in the piglets having $16 \mathrm{mg}$ Se per $\mathrm{kg}$ in their diet (Goehring et al. 1984). In the pre- sent study the piglets fed $16 \mathrm{mg}$ Se per $\mathrm{kg}$ had only about $14 \%$ reduction in feed intake and the feed utilization was not affected. Wahlstrom \& Olson (1959b) fed piglets $10 \mathrm{mg} \mathrm{Se}$ per $\mathrm{kg}$ feed and reported that piglets from sows fed selenized rations $(10 \mathrm{mg}$ Se per kg feed) for a long period of time appeared to be more resistant to Se toxicity than others. This observation could explain the divergency between the present results and those obtained by Goehring et al. (1984).

Wahlstrom et al. (1984) found that red pigs were more susceptible to Se surplus than white and black pigs. This could also be an interpretation of the disagreement between results obtained in the various experiments. It might be a reasonable explanation as previous studies based on analyses of blood (Jensen et al. 1979) reported a genetic influence on the activity of the enzyme glutathione peroxidase. Stowe \& Miller (1985) also reported that pigs are predisposed to hypoor hyperselenemia and found that the absorption of Se in pigs is genetically influenced (Stowe \& Miller 1986).

It is worth noting that no clinical signs on Se toxicosis were observed among the young sows, even if they had $16 \mathrm{mg}$ Se per $\mathrm{kg}$ in their feed for about 6 months. This finding is in agreement with that of Casteel et al. (1985), who found that after 6 weeks of feeding rations with $\mathrm{Se}$ concentrations between 9.7 and $27 \mathrm{mg}$ per $\mathrm{kg}$, piglets and sows were unaffected whereas a group of feeder pigs weighing more than 50 pounds developed a fatal paralytic disease. Differences in the Se intake per $\mathrm{kg}$ body weight together with physiological variations may influence the response. Feed refusal as seen in this and other experiments (Wilson et al. 1983, Goehring et al. 1984) could be an explanation for the apparently higher resistance in young pigs. Further studies are 
needed concerning the capability of pigs to excrete Se given in excess in pointing out at which level, Se becomes toxic to pigs at different ages.

The results from the present study indicate that high dietary Se (up to $16 \mathrm{mg}$ per $\mathrm{kg}$ feed) given as sodium selenite had no detrimental effect on the reproductive performance of primiparous sows. There was a tendency to a lower body weight of the piglets at birth. From weaning until 9 weeks of age, high dietary Se resulted in reduced daily feed intake and weight gain.

\section{Acknowledgements}

This study received financial support from "Research Officer R. Nørtoft Thomsen's Foundation". For assistance in the clinical examinations of the sows and piglets, the authors thank $\mathrm{dr}$. N. C. Nielsen, Royal Veterinary and Agricultural University, Copenhagen. For advice concernıng the reproductive performance thanks are due to Dr. L. H. Hansen, Royal Veterinary and Agricultural University, Copenhagen.

\section{References}

Casteel SW, Osweller GD, Cook WO, Daniels G, Kadlec $R$ Selenium toxicosis in swine. J. Amer. vet. med. Assoc. 1985, 186, 10841086.

Chavez ER. Nutritional significance of selenium supplementation in a semi-purified diet fed during gestation and lactation to first-litter gilts and their piglets. Can. J. Anim. Sci. 1985, 65, 497-506.

Goehring TB, Palme IS, Olson OE, Libal GW, Wahlstrom $R C$ : Toxic effects of selenium on growing swine fed corn-soybean meal diets. J. Anım. Sci. 1984, 59, 733-737.

Harrison LH, Colvin BM, Stuart BP, Sangster LT, Gorgacz EJ, Gosser HS. Paralysis in swine due to focal symmetrical poliomalacia: possible selenium toxicosis. Vet. Pathol. 1983, 20, 265-273.

Jensen PT, Danielsen V, Nielsen $H E$. Glutathione peroxidase activity and erythrocyte lipid peroxidation as indices of selenium and vita- min E status in young pigs. Acta. vet. scand. 1979, 20, 92-101.

Just $A$ The net energy value of balanced diets for growing pigs. Livest. Prod. Sci. 1982, 8, 541-555.

Mahan DC, Moxon $A L$ : Effect of inorganic selenium supplementation on selenosis in postweanıng swine. J. Anim. sc1. 1984, 58, 12161221.

Meyer WR, Mahan DC, Moxon $A L$ Value of dietary selenium and vitamin $\mathrm{E}$ for weanling swine as measured by performance and tissue selenium and glutathione peroxidase activities. J. Anım. Sci. 1981, 52, 302-311.

Nielsen HE, Danielsen V, Simesen MG, GisselNielsen $G$, HJarde $W$, Leth $T$, Basse $A$. Selenium and vitamin $E$ deficiency in pigs. I. Influence on growth and reproduction. Acta vet. scand. 1979, 20, 276-288.

Rotruck JT, Pope AL, Ganther HE, Swanson AB, Hafeman DG, Hoekstra WG. Selenium: Biochemical role as a component of glutathione peroxidase. Science 1973, 179, 588-591.

SAS Instttute Inc SAS User's Guide: Statistics. Cary NC: SAS Institute Inc. 1982.

Stowe HD, Miller ER . Genetic predisposition of pigs to hypo- and hyperselenemia. J. Anım. Sci. 1985, 60, 200-211.

Stowe HD, Miller ER Genetic influence on selenium absorption in pigs. Proceedings Sixth International Conference on Production Disease in Farm Animals 1986, 163-166.

Wahlstrom RC, Olson $O E$ The effect of selenium on reproduction in swine. J. Anım. Sci. 1959a, 18, 141-146.

Wahlstrom $R C$, Olson $O E$ The relation of prenatal and pre-weaning treatment to the effect of arsanilic acid on selenium poisoning in weanling pıgs. J. Anım. Sci. 1959b, 18, 578582.

Wahlstrom RC, Goehring TB, Johnson DD, Llbal $G W$, Olson $O E$, Palmer IS, Thaler $R C$ The relationship of hair color to selenium content of hair and selenosis in swine. Nutr. Rep. Inter. 1984, 29, 143-147.

Wilson TM, Scholz $R W$, Drake TR. Selenium toxicity and porcine focal symmetrical poliomyelomalacia: Description of a field outbreak 
and experimental reproduction. Can. J. Comp. Med. 1983, 47, 412-421.

\section{Sammendrag}

Store mangder selen tul førstelagssøer og deres afkom I Effekt på reproduktıon og voekst.

Effekten af tilsætnıng af stigende mængder selen op til $16 \mathrm{mg}$ pr. kg foder til førstelægssøer og deres afkom blev undersøgt. Der sås ingen toksisk effekt på reproduktionsevne og vækst. Ingen søer døde af forsøgsbehandlingen. Alle smågrise var fuldbårne og viste ikke makroskopiske forandringer. Smågrisene fra søerne, der fik stort tilskud af selen havde lidt lavere fødselsvægt, men smågrisedødeligheden var upåvirket af behandlingen. I perioden efter fravænning havde grisene, der fik 8 eller 16 mg selen pr. $\mathrm{kg}$ foder, en mindre foderoptagelse. Forskellen 1 smågrisenes vægt ved 9 uger var signifikant lavere for de højeste selenniveauer, medens foderudnyttelsen var ens for alle forsøgsbehandlinger.

\section{(Recelved September 12, 1988; accepted December 14, 1988)}

Reprints may be requested from: Hanne Damgaard Poulsen, Department for Research in Pigs and Horses, National Institute of Animal Science, Foulum, P. O. Box 39, DK-8830 Tjele, Denmark. 